\title{
Mewartakan Injil - Menahan Roti: Sebuah Refleksi Kritis Model Pelayanan Yudas
}

Hendrikus Nayuf

Sekolah Tinggi Teologi Intim Makassar

hendrikusnayuf@yahoo.com

\begin{abstract}
Poverty is often used as an excuse for fighting for justice and solidarity. Poverty becomes a magnet for anyone to raise it as an issue of partiality. Even poverty can be used as a means of struggle to criticize the leaders of the nation and the church. Jude, one of Jesus disciples show this in Jesus anointing narrative in Bethany. Jude fought for justice while at the same time showing his solidarity when criticizing Mary for anointing Jesus by using expensive aromatic oil. At the symbol level, Judas shows a concrete emphaty attitude. He showed partiality and dared to rebuke others so that they were not wasteful while poverty was so rampant. Even though Jude's attitude was counter-productive with narratives about him. But the story becomes an inspiration and source of learning about the interpretation of poverty and also a warning sign for church leaders so that in their works, the must "proclaim the Gospel - share bread" and not "proclaim the Gospel - hold bread."
\end{abstract}

Keywords: bread; Jude; gospel; poverty; solidarity

Abstrak: Kemiskinan sering dijadikan alasan dalam memperjuangkan keadilan dan solidaritas. Kemiskinan menjadi magnet bagi siapa saja untuk mengangkatnya sebagai isu keberpihakan. Bahkan kemiskinan dapat dijadikan sebagai alat perjuangan untuk mengkritisi para pemimpin bangsa maupun pemimpin gereja. Yudas, salah satu murid Yesus telah menunjukkan hal tersebut dalam narasi pengurapan Yesus di Betania. Yudas memperjuangkan keadilan sekaligus menunjukkan sikap solidaritasnya saat mengkritik Maria yang mengurapi Yesus dengan menggunakan minyak narwastu yang mahal. Dalam tataran simbol, Yudas menunjukkan sikap empati yang konkrit. Ia menunjukkan keberpihakan dan berani menegor orang lain agar tidak berlaku boros sementara kemiskinan begitu merajalela. Walau sikap Yudas kemudian kontra produktif dengan kelanjutan narasinarasi tentang dirinya. Tetapi kisahnya kemudian menjadi inspirasi dan sumber pembelajaran tentang penafsiran atas kemiskinan dan juga tanda awas bagi para pemimpin Gereja agar dalam karya-karyanya, harus "mewartakan Injil - membagi roti" dan bukan "Mewartakan Injil - Menahan Roti."

Kata kunci: kemiskinan; Injil; roti; solidaritas; Yudas

$\begin{array}{llll}\text { Article History: } & \text { Received: 03-12-2018 } & \text { Revised: 19-12-2018 } & \text { Accepted: 26-12-2018 }\end{array}$




\section{Pendahuluan}

Desain di balik pemanggilan kedua belas murid Yesus adalah kelak mereka menjadi pemimpin. Salah satu frasa yang menegaskan desain itu adalah "Ia menetapkan dua belas orang untuk menyertai Dia dan diutusnya untuk memberitakan Injil."(Mrk.3:14). Ada kuasa yang diberikan kepada kedua belas murid sebagai "alat kelengkapan dan hak istimewa" dalam menjalankan amanat tersebut. Markus mencatat alat kelengkapan dan hak istimewa "kuasa untuk mengusir setan" (Mrk.3:15). Matius, menulis, "kuasa...untuk mengusir roh-roh jahat dan untuk melenyapkan segala penyakit dan segala kelemahan." (Mat.10:1). Sementara Lukas tidak menuliskan alat kelengkapan dan hak istimewa dari para murid yang dipanggil, namun yang menjadi catatan khusus dalam Lukas dalam kisah pemanggilan murid-murid adalah pemanggilan kedua belas murid diawali dengan doa. Lukas menulis begini, "Pada waktu itu pergilah Yesus ke bukit untuk berdoa semalam-malaman Ia berdoa kepada Allah. Ketika hari siang, Ia memanggil muridmurid-Nya..." (Luk. 6:12,13a). Berbagai kuasa yang diberikan kepada para murid diawal pemanggilan dipertegas kembali ketika Yesus bersama para murid mengadakan berbagai pelayanan. Misalnya, dalam "evaluasi" di Kaisarea Filipi, saat Yesus bertanya kepada para murid tentang siapa Diri-Nya, Ia merespon jawaban Petrus dengan menyatakan, "Kepadamu akan Kuberikan kunci Kerajaan Sorga. Apa yang kau ikat di dunia ini akan terikat di Sorga dan apa yang kau lepaskan di dunia ini akan terlepas di Sorga." (Mat. 16:19). Begitu juga, ketika di Galilea, saat "detik-detik terakhir", Yesus mengulang kembali hak yang melekat dalam diri para murid sebagai pemimpin, "...dan ajarlah mereka melakukan segala sesuatu yang telah Kuperintahkan kepadamu." (Mat. 28:19).

Catatan-catatan dari Injil menegaskan satu hal, bahwa para murid dipersiapkan untuk meneruskan ajaran yang telah disampaikan oleh Yesus. Persiapan yang dilakoni oleh para murid merupakan bagian penting dari proses kaderisasi. Para murid tidak menyadari dinamika tersebut, tetapi Yesus yang berorientasi pada pembangunan Kerajaan Sorga, berada pada alur itu. Artinya, Yesus sementara menyampaikan pesan "kesediaan" untuk nantinya memberikan tongkat estafet kepemimpinan kepada para murid.

Pertanyaannya adalah bagaimana respon para murid atas dinamika yang mereka jalani bersama Yesus? Banyak narasi yang dijumpai dalam Injil terkait respon tersebut. Dalam tulisan ini, penulis hendak mengkaji respon Yudas. Mengapa Yudas? Alasan pertama, ia adalah salah satu murid yang dipanggil, dipilih dan ditetapkan oleh Yesus. Bahkan, ketika merujuk pada Injil Lukas, Yesus menggumuli panggilan dan keterpilihan Yudas sebelum ditetapkan sebagai murid dalam doa. Kedua, terkait dengan cerita tentang pengurapan Yesus di Betania, Injil Yohanes secara konkrit menyebut Yudas sebagai "mereka" yang tidak setuju dengan tindakan perempuan yang meminyaki Yesus dengan minyak narwastu murni yang mahal harganya. (Yoh. 12:4). Ketiga, di dalam Injil Markus, setelah cerita tentang pengurapan di Betania, Yudas segera menjumpai para imam kepala dengan maksud untuk menyerahkan Yesus kepada mereka (Mrk.14.10). Keempat, Yudas adalah pemegang kas yang memiliki orotitas untuk melakukan transaksi keuangan terkait dengan perjalanan mereka. Yudas juga memiliki kewenangan untuk "memberi apa-apa kepada orang miskin" (Yoh.13:29c). Kelima, ada penyesalan atas perbuatannya. Matius menyaksikan, "Pada waktu Yudas, yang menyerahkan Dia, melihat, bahwa Yesus telah dijatuhi hukuman mati, menyesallah ia..." (Mat.27:3). Kelima alasan ini menjadi dasar dalam penetapan topik di atas sebagai pokok tulisan ini. Tulisan ini secara khusus akan mengkaji gaya kepemimpinan Yudas, kewenangan dan respon atas kepercayaan yang ia terima. Pada akhir tulisan ini, kita akan mengambil makna di 
balik tokoh Yudas sebagai salah satu murid Yesus sebagai refleksi atas kepemimpinan gereja masa kini.

\section{Metode Penelitian}

Pokok-pokok yang dijabarkan dalam tulisan ini dikembangkan dengan menggunakan pendekatan kualitatif dengan melihat tiga dimensi penting, yakni interpretatif, hermeneutis dan konstruksi sosial. ${ }^{1}$ Ketiga dimensi di atas diperoleh melalui studi pustaka terhadap topik tulisan ini.

\section{Hasil dan Pembahasan}

\section{Yudas dan Stigma}

Terlepas dari tindakan Yudas di akhir kebersamaannya dengan Yesus, catatancatatan Injil menegaskan satu hal, bahwa Yudas terpilih bersama sebelas teman lainnya untuk menerima kuasa sebagai pengusir kuasa-kuasa jahat, melenyapkan segala penyakit dan segala kelemahan (Mat.10:1), memberitakan Injil dan mengusir setan (Mrk. 3:14,15). Keterpilihan Yudas memberi indikasi bahwa dia memenuhi kriteriakriteria sebagai murid Yesus. Yudas terpilih menjadi salah satu murid bukan karena nepotisme melainkan "hasil doa" dari Yesus (Luk. 6:12). Bahkan dalam Injil Yohanes, penulis menjelaskan posisi Yudas sebagai "pemegang kas" dalam kelompok dua belas (murid-murid Yesus).

Di samping kuasa-kuasa yang diberikan kepadanya sebagai salah satu murid Yesus, dalam kelanjutan narasi-narasi tentang dirinya, para penulis Injil, baik Sinoptik maupun Yohanes, seakan sepakat bahwa ia "telah ditetapkan" sebagai pengkhianat. Markus dan Matius memberikan penjelasan tentang Yudas dalam daftar nama murid-murid Yesus, “...yang mengkhianati Dia.” (Mrk. 3:19; Mat.10:4). Lukas juga menyampaikan hal yang sama, “...dan Yudas Iskariot yang kemudian menjadi pengkhianat." (Luk. 6:16). Mempertegas penjelasan-penjelasan dalam Injil Sinoptik, Yohanes kemudian merinci perilaku Yudas, “... ia adalah seorang pencuri; ia sering mengambil uang yang disimpan dalam kas yang dipegangnya." (Yoh.12:6). Setelah pembasuhan kaki murid-murid-Nya, Yesus secara tidak langsung "membuka rahasia" tentang salah satu murid yang akan mengkhianati diri-Nya. Yesus menyatakan, "Aku berkata kepadamu, sesungguhnya seorang di antara kamu akan menyerahkan Aku." (Yoh.13:21b). Yesus kemudian secara terbuka memberi tanda tentang sang pengkhianat, "Dialah itu, yang kepadanya Aku akan memberikan roti, sesudah Aku mencelupkannya.... Ia mengambil roti, mencelupkannya dan memberikannya kepada Yudas, anak Simon Iskariot." (Yoh.13:26).

Penyebutan "sebagai pengkhianat" yang ditujukan kepada Yudas disebut stigma. Stigma berarti ciri negatif yang menempel pada pribadi seseorang karena pengaruh lingkungan. Secara sederhana stigma berbicara tentang penilaian terhadap tindakan atau perilaku seseorang. Menurut Mochammad Yuniar, stigma adalah cap atau persepsi negatif seseorang atau golongan akan kehidupan kita atau kegiatan yang kita lakukan. Stigma adalah berbagai pandangan orang yang menilai kita negatif, hal yang kita lakukan negatif sampai pemikiran kita negatif. ${ }^{2}$ Dua pengertian ini menunjukkan bahwa para

\footnotetext{
1 John Haba, Pendekatan Kualitatif, dalam Robert Setio, Julianus Moaju, Yusak Sulaiman, H. Ongirwalu, (Penyunting), Prosiding: Studi Institut dan Metodologi Riset Ilmu Teologi, Tomohon, Fakultas Teologi, UKIT, 2012), 6-7.

2 Mochammad Yuniar, Hidup dalam Stigma=Hidup Terpenjara, dalam www.kompasiana.com (diakses 26 Oktober 2018).
} 
penulis Injil telah memberi catatan negatif atas perilaku Yudas pasca keterpilihannya sebagai salah satu murid Yesus.

Terdapat dua kemungkinan yang dapat dianalisis dari perilaku Yudas. Pertama, Yudas tidak membayangkan bahwa dirinya akan menikmati "fasilitas yang tersedia," sebagai kompensasi atas keterpilihannya sebagai salah satu murid Yesus. Analisis ini dikembangkan dari tesis yang dikembangkan oleh Gerd Theissen, bahwa Yesus tidak ada pada jalur untuk menciptakan komunitas lokal. Ia hanya membentuk suatu gerakan karismatik jalanan. ${ }^{3}$ Yudas "sepertinya" terkejut, ketika ia dan teman-temannya "hanya berjalan" di sekitar Galilea. Yudas seakan tidak percaya, kalau Yesus pun tidak memiliki tempat untuk membaringkan kepala-Nya. Yudas sesungguhnya "berharap" sebuah "sekertariat" untuk menata jadwal pengajaran, pengusiran kuasa-kuasa jahat dan visitasi.

Suasana kebatinan Yudas ini terkonfirmasi dengan apa yang dikatakan oleh Theisen, bahwa gerakan mereka bukanlah suatu bentuk hidup yang terlembaga, sebuah posisi di mana seseorang dapat bergabung sebagai akibat dari keputusan pribadinya semata-mata. ${ }^{4}$ Karena itu, ketika ia diberikan kuasa untuk memberitakan Injil, mengusir kuasa-kuasa jahat, melenyapkan segala penyakit dan segala kelemahan, bahkan sebagai pemegang kas, ia berada pada suasana "lepas kontrol." Berjalan ke sana-ke mari bersama Yesus dan murid-murid yang lain, menyaksikan berbagai mujizat dan dieluelukan oleh orang banyak tentunya berkontribusi atas "suasana lepas kontrol" tersebut. Di samping itu, gaya kepemimpinan Yesus yang mengedepankan pendekatan fungsi daripada hirarkhi juga menjadi semacam angin segar bagi dirinya untuk bertindak melebihi kewenangan yang ia peroleh.

Kedua, keterpilihan Yudas dapat dimaknai sebagai sebuah keputusan di luar dirinya. Merujuk pada penjelasan Lukas, “...Ia memanggil murid-murid-Nya kepada-Nya, lalu memilih di antara mereka dua belas orang...” (Luk. 6:13) maka dipastikan bahwa keterpilihan Yudas berada di luar perkiraan dirinya. Jadi, karakter murid-murid yang dibentuk dari model pemilihan dan juga konteks pelayanan seperti yang terjadi pada para murid menunjuk pada apa yang disebut Gerd Theisen sebagai kelompok karismatik jalanan. Mereka menjalankan sesuatu yang berada di luar kontrolnya sendiri. ${ }^{5}$ Mereka dipengaruhi oleh cara berpikir dan bertindak yang dikendalikan oleh orang lain.

Pengaruh yang didapatkan adalah perubahan pandangan dari model sektarian ke bimbingan manusia secara keseluruhan. ${ }^{6}$ Tidak ada kesempatan untuk mengelaborasi potensi diri sebagai kekuatan internal dalam menjawab tuntutan publik sebagai seorang murid Yesus. Ia berada pada posisi mengikuti alur dan cara hidup Yesus dan temantemannya. Dalam situasi ini, benar kata-kata Constantin Stanislavski sebagaimana dikutip Kevin J. Vanhoozer, "Jangan pernah membiarkan dirimu di luar menggambarkan sesuatu yang tidak kamu alami secara batiniah dan dan yang bahkan tidak menarik bagimu."7

Memang stigma negatif yang dijelaskan oleh para penulis Injil terhadap sosok Yudas kemudian "seakan dipulihkan" melalui sikap penyesalan dan gantung diri. Tetapi sikap tersebut sering kalah greget dengan stigma pengkhianat. Dampaknya adalah

\footnotetext{
${ }^{3}$ Gherd Theisen, Gerakan Yesus, Sebuah Pemahaman Sosiologis tentang Jemaat Kristen Perdana, (Maumere:Ledalero, 2005), 15.

4 Ibid., 16.

5 Ibid.

${ }^{6}$ Bnd. Justin Taylor, Asal-Usul Agama Kristen (Yogyakarta: Kanisius, 2008), 142.

${ }^{7}$ Kevin J. Vanhoozer, Drama Doktrin, Suatu Pendekatan Kanonik-Linguistik pada Theologi Kristen (Surabaya: Penerbit Momentum, 2011), 501.
} 
Yudas merupakan sosok yang kalah dalam sejarah. Kenangan akan Yudas adalah kenangan akan pengkhianatan. Orang akan mengingatnya sebagai pengkhianat. Bagi mereka yang mengalami situasi tersebut, oleh Walter Benjamin disebut sebagai kelompok yang kalah dalam sejarah. ${ }^{8}$ Sosok Yudas dinarasikan secara kontras dengan "keberanian sejarah" yang selalu berusaha untuk mengangkat berbagai cerita kelam masa lalu yang cenderung ditutup-tutupi karena ketokohan pelaku sejarah tersebut. Dalam narasi seperti inilah stigma yang dilekatkan pada Yudas sulit dihapus.

Stigma benar-benar membenamkan sosok Yudas lalu menghapusnya dari narasi persaudaraan yang dibangun bersama Yesus dan teman-temannya kurang lebih tiga tahun. Stigma terhadap Yudas adalah requiem kematian kekal tanpa halleluyah kebangkitan bagi semua yang tak berdaya. ${ }^{9}$ Dalam upacara requiem nyanyian pengkhianatan terus dilantunkan untuk mengingat Yudas. Sementara sorak-sorai kebangkitan seakan menjadi hak para penulis sejarah yang sangat paham mempermainkan suasana kebatinan para pembaca. Di sinilah stigma negatif membunuh semua yang pernah Yudas kerjakan.

\section{Yudas dan Penafsiran atas Kemiskinan}

Salah satu hal penting yang menjadi pokok percakapan dalam tulisan ini adalah "keberpihakan Yudas" atas nasib orang-orang miskin. Keberpihakan tersebut ditunjukan Yudas dengan pendekatan solidaritas. Yudas menunjukkan tanda protes dengan nada keberpihakan saat ia menyatakan, "Mengapa minyak narwastu ini tidak dijual tiga ratus dinar dan uangnya diberikan kepada orang-orang miskin?" (Yoh. 12:5). Dalam versi Matius, "Untuk apa pemborosan ini? Sebab minyak itu dapat jual dengan mahal dan uangnya dapat diberikan kepada orang-orang miskin" (Mat.26:8). Markus juga mengatakan hal yang dikutip oleh Matius dalam menyampaikan protes murid-murid atas pengurapan Yesus. Alasan mereka (murid-murid, yang secara konkrit, dalam Yohanes justru menyebut bukan "mereka" melainkan Yudas) sangat profetik: solider dengan orang miskin.

Atas sikap tersebut J.LCh. Abineno menyatakan, rupanya pekerjaan diakonia dapat disalahgunakan oleh Yudas Iskariot untuk kepentingan dirinya sendiri. 10 Penyalahgunaan itu dilatarbelakangi oleh motivasi yang tidak tulus dalam keberpihakan kepada orang-orang miskin. Abineno menegaskan, bahwa ucapan Yudas (berdasarkan kesaksian Yohanes), mempunyai motif yang lain. Bukan karena ia mencintai orangorang miskin, tetapi karena ia adalah seorang pencuri. ${ }^{11}$

Yang menarik adalah, reaksi Yesus atas sikap Yudas tersebut. Yesus menyatakan, “Karena orang-orang miskin selalu ada pada kamu..." (Yoh. 12:8; Matius dan Markus pun menyatakan hal yang kurang lebih sama). Yesus mengutip Ulangan 15:11, yang secara lengkap mengatakan, "Sebab orang-orang miskin tidak hentinya akan ada di negeri itu; itulah sebabnya aku memberi perintah kepadamu demikian: Haruslah engkau membuka tangan lebar-lebar bagi saudaramu, yang tertindas dan yang miskin di negerimu."Jika kita merujuk pada ayat Kitab Taurat yang dikutip oleh Yesus, maka penafsiran Yudas terhadap kemiskinan yang menjadi "objek diakonia” dalam kisah

8 Paul Budi Kleden, "Memasang Panggung ke Masa Depan-Menyisir Masa Lampau, Menyimak Filsafat Sejarah Walter Benjamin," dalam Frans Ceunfin dan Felix Baghi, Mengabdi Kebenaran (Maumere: Penerbit Ledalero, 2005), 94.

9 Ibid., 96.

10 J. L. Ch. Abineno, Yesus Sang Mesias dan Sang Anak, (Jakarta: BPK Gunung Mulia, td), 209.

11 Bnd, Ibid. 
pengurapan di Betania adalah cara menafsir yang mengedepankan "kepentingan personal-keserakahan".

Cara menafsir model seperti ini kurang lebih sama seperti model penafsiran alegoris yang cenderung bertahan dalam klaim "pembenaran" teologi dan ajaran "kami". Yudas berada pada posisi "mengamankan" ajaran Yesus tentang keberpihakan pada orang-orang miskin. Yudas pun paham, bahwa apa yang ia lakukan adalah bagian dari refleksi dan rencana aksi keberpihakan sebagaimana ditegaskan dalam Taurat, "...haruslah engkau membuka tangan lebar-lebar bagi....yang miskin di negerimu." Dalam analisis sosiologis, penafsiran Yudas atas kemiskinan didasarkan pada apa yang Gerd Theissen sebut sebagai reaksi negatif atas situasi yang dihadapi. Theissen menyatakan, "seseorang yang tidak puas dengan situasi sebagaimana adanya bisa menjadi seorang penjahat..."12 Penafsiran Yudas atas kemiskinan didasarkan pada ketidakpuasannya menyaksikan pengurapan Yesus yang dilakukan oleh Maria dengan menggunakan minyak narwastu murni.

Bagi Yudas, Yesus mestinya menolak tindakan tersebut. ${ }^{13}$ Dalam konteks ini, Yudas berada dalam situasi hitung-hitungan untung rugi. Kata-kata keberpihakannya dilandaskan pada kalkulasi pragmatis yang ada di depan matanya. Ia tidak berpikir tentang investasi keselamatan yang secara tersirat ditegaskan oleh Yesus. Inilah situasi yang oleh Paul Tillich disebut sebagai pengabaian akan makna pengayaan kehidupan pribadi, melainkan kalkulasi nilai ekonomi capital. Paul Paul Tillich, menyatakan, "things become wares - object whose meaning lies in the production of profits in transactions of buying and selling, not in the enrichment of the personal life." 14 Paul Tillich hendak menggambarkan bahwa kepemimpinan gereja berada dalam konteks hitung-hitungan tersebut. Situasi yang sementara ada dan berkembang di tengah-tengah dinamika religiositas masyarakat.

Kembali pada pernyataan Yesus, bahwa “...orang-orang miskin selalu ada pada kamu...." (Yoh. 12:8a). Pernyataan ini memberi "signal" bagi kita untuk mencari tahu siapa itu orang miskin? Menurut J. B. Banawiratma, kaum miskin sekarang tidaklah jauh berbeda dengan kaum miskin sebagaimana ditemukan dalam Kitab Suci Perjanjian Lama (PL) dan Perjanjian Baru (PB). ${ }^{15}$ Bagi Banawiratma, berdasarkan penelitian G. Soares Prabhu, yang dimaksud kaum miskin dalam Kitab Suci PL dan PB adalah: pertama, kelompok sosial dengan identitas yang ditentukan bukan oleh sikap religius mereka melainkan oleh situasi sosial mereka. Jadi, bukan hanya kemiskinan rohani, melainkan kemiskinan fisik. Kedua, kaum miskin dalam Alkitab juga merupakan kelompok dialektis. Maksudnya, situasi mereka ditentukan oleh pertentangan kelompok-kelompok yang bertindak tidak adil dan menyingkirkan mereka. Ketiga, kaum miskin dalam Kitab Suci adalah kelompok yang dinamis. Mereka bukanlah kelompok-kelompok pasif dalam sejarah. Melalui dan bersama mereka, Allah membentuk sejarah-Nya.

Aloysius Pieris membuat kategori-kategori yang lebih terperinci mengenai kaum miskin dalam Injil: (a) mereka yang secara sosial dikucilkan (karena penyakit lepra dan penyakit jiwa); (b) mereka yang secara sosial bergantung pada orang lain (janda dan yatim piatu); (c) mereka yang secara religius dibuang (pelacur dan pemungut cukai); (d) mereka yang secara kultural ditundukkan (kaum perempuan dan anak); (e) mereka yang secara fisik cacat (bisu - tuli, buntung kaki, buta); (f) mereka yang secara psikologi

\footnotetext{
12 Thessen, Gerakan Yesus, 69.

13 Abineno, Yesus Sang Mesias dan Sang Anak, 209.

${ }^{14}$ Paul Tillich, The Religious Situasion (New York: Meridian Books, 1958), 106.

15 J. B. Banawiratma, 10 Agenda Pastoral Transformatif (Yogyakarta : Kanisius, 2001), 10.
} 
tersiksa (kerasukan setan, ayan); (g) mereka yang secara spiritual rendah hati (orangorang yang sederhana yang takut akan Allah dan para pendosa yang bertobat). ${ }^{16}$

Kedua pengelompokan di atas paling tidak menolong kita untuk melihat bahwa penafsiran Yudas atas kemiskinan didasarkan pada pertimbangan personal. Pertimbangan itu yang memungkinkan dia untuk mengekspresikan suasana kebatinannya sebagai wujud keberpihakan kepada kaum miskin. Walaupun keberpihakan itu kemudian disebut sebagai ekpresi keserakahan. Sebuah niat untuk memperkaya diri dengan memanfaatkan konteks kemiskinan sebagai "pintu masuk."

\section{Konsekuensi dari sebuah Keputusan}

Keputusan Yudas untuk menjual Yesus berakibat pada pemberlakuan hukum yang tidak memberi ruang bagi korban untuk membela diri. Yesus sebagai "terdakwa korban" diperhadapkan pada dakwaan yang sudah diputuskan "sebelum" persidangan. Menyaksikan drama tersebut, Yudas menyesal dan berkata, "Aku telah berdosa karena menyerahkan darah orang yang tak bersalah." (Mat. 27:4). Secara konkrit Yudas pun melakukan dua hal sekaligus: "menyesal lalu mengembalikan uang yang tiga puluh perak itu kepada imam-imam kepala dan tua-tua...” (Mat.27:3).

Tindakan "menyesal" dan "mengembalikan uang hasil penjualan Yesus" merupakan sebuah ekpresi pertanggungjawaban atas keputusan yang telah diambil oleh Yudas. Tindakan ini didasarkan pada dua hal. Pertama, kedekatan Yudas dengan Yesus memberi ruang bagi dirinya untuk mengikuti setiap proses hukum yang sementara dijalani oleh Yesus. Dan, ketika ia menyaksikan bahwa Yesus tidak bersalah, maka menyesallah ia. Artinya, ada kesadaran bahwa tindakan yang telah ia tempuh merupakan sebuah kelalaian dalam mengambil keputusan. Kedua, sepertinya ada kesadaran baru dari Yudas bahwa ia dimanfaatkan oleh kelompok Sanhendrin.

Menurut analisis Gerd Theissen, sejak tampilnya Yesus di depan publik, telah terjadi ketegangan antara Yesus dan kaum aristocrat Negara berbasis kanisah (agama). Menurut Theissen, perhatian mereka atas gerakan Yesus terkait dengan sikap kritis Yesus atas pembersihan kanisah (Mrk. 11:15); posisi relatif yang diberikan kepada kanisah dalam hubungan dengan rekonsiliasi dan sumpah (Mat.5:23-24.33-37; 23:1619), dan ramalan-ramalan kenabian mengenai kenisah (Mrk. 14:58-59; Kis. 6:14; Mat. 23:28). ${ }^{17}$ Kesadaran ini "baru muncul" dalam benak Yudas ketika ia mengikuti proses persidangan yang dijalani oleh Yesus. Sebab, Yudas tentunya mengetahui bahwa orang yang memberikan posisi relatif dan bukan absolut terhadap kanisah dan hukum dianggap tengah menyerang hak-hak istimewa kaum aristokrat imamat. 18 Kosekuensinya adalah hukuman mati. Dan, Yesus berada dalam radar para aristorkrat tersebut. Mereka mencari celah untuk menangkap dan menyerahkan Yesus kepada pengadilan. Ketika Yudas menjumpai mereka dan menyampaikan niat untuk menyerahkan Yesus, maka mereka sangat antusias untuk mengeksekusi Yesus.

Dalam konteks itu, Yudas seperti beranjangsana pada setiap detik yang ia lalu bersama Yesus bahkan ketika Yudas menjumpai para imam dan hali Taurat. Yudas terus membuka kembali file-file yang ia simpan dalam perbendaharaan persekutuan mereka. Ia terpana membaca setiap kegiatan yang dilakukan oleh Yesus. Ia tidak menemukan setiap celah untuk menyerahkan Yesus kepada para penyamun. Ia akhirnya menempuh

\footnotetext{
${ }^{16}$ Aloysius Pieris, Berteologi dalam Konteks Asia (Yogyakarta : Kanisius, 1996), 116.

17 Theissen, Gerakan Yesus, 137.

18 Bnd. Ibid.
} 
cara "gentlemen", meminta maaf dan mengembalikan uang para imam kepala dan ahli Taurat.

Terlepas dari stigma yang telah dialamatkan kepada Yudas, tetapi sikap keberanian untuk mengakui salah dan berani mengembalikan uang yang telah ia peroleh merupakan sebuah keputusan elegan. Ia harus menerima resiko penolakan dari para ahli Taurat dan para imam. Jika ia tidak mengakhiri hidupnya melalui cara gantung diri, ada kemungkinan ia pun ditolak oleh sahabat-sahabatnya. Sebuah kemungkinan yang dikemukakan oleh Theissen menarik untuk direfleksikan. Theissen menyatakan, "kemungkinan besar Sanhendrin merupakan penggerak-penggerak utama dalam gerakan penganiayaan terhadap Yesus."19 Yudas, dalam konteks "konsekuensi dari sebuah keputusan" berada dalam posisi yang sangat geram atas kemungkinan tersebut. Ia berada pada tekanan psikologi personal yang tidak mudah. Dalam tekanan seperti itulah ia mengambil sebuah keputusan sebagai konsekuensi atas keputusan yang ia ambil sebelumnya.

Terdapat analisis lain terkait dengan topik kecil ini, yakni pengaruh ajaran Yesus yang justru memberi dampak bagi Yudas setelah drama penangkapan di Taman Getsemani. Ketika di Taman Getsemani, Yudas menyaksikan tindakan Yesus yang tidak melawan. Ia menyaksikan bagaimana Yesus menunduk lalu memungut telinga Malkhus yang ditebas oleh salah seorang murid-Nya. Pengalaman itu memberi dampak bagi Yudas setelah ia diperhadapkan pada penolakan dari imam-imam kepala dan ahli-ahli Taurat. Yudas "menyadari" bahwa ia telah keliru mengambil keputusan. Walau demikian, persoalan yang dihadapi oleh Yudas adalah ia telah dikerangkeng dalam bingkai stigma sebagai seorang penjahat. Bingkai ini yang kemudian dapat dijadikan sebagai salah satu kemungkinan bagi Yudas untuk mengakhiri hidupnya.

\section{Catatan Kritis atas Keputusan Yudas}

Injil Matius dan Markus mencatat, bahwa setelah peristiwa pengurapan di Betania, Yudas memutuskan menjumpai imam-imam kepala untuk bersama-sama menyusun siasat penangkapan Yesus (Mat.26:14-16; Mrk. 14:10). Dalam Injil Yohanes, cerita tentang keputusan Yudas meninggalkan Yesus dan teman-temannya justru setelah Yesus membasuh murid-murid-Nya (Yoh 13). Yohanes menyatakan, “...lalu segera pergi”. (Yoh. 13:20). Keputusan tersebut diambil setelah Yesus dengan tegas menyampaikan, bahwa “...sesungguh seorang di antara kamu akan menyerahkan Aku." (Yoh.13:21). Artinya, keputusan Yudas dilatarbelakangi oleh konteks hidup, lingkungan dan motivasinya.

Keputusan Yudas pertama-tama bukan karena dorongan dari dirinya akibat trauma atau karena seperti "tuduhan Yohanes" bahwa ia adalah seorang pencuri. Jika kita sejenak memandang "spion" masa kematian Yesus, tergambar secara jelas, bahwa justru yang meneteskan air mata adalah kalangan Yahudi, termasuk di dalamnya golongan keturunan Yudas. Benar, bahwa orang-orang Yahudi yang berteriak-teriak di depan pengadilan agar menyalibkan Yesus, tetapi itu terjadi akibat kekuasaan Romawi. 20 Kalangan Yahudi dikuasa oleh Romawi dengan menempatkan prefek dan prokurator dibawah kendali kekuasaan imperium Romawi. Sebab, orang-orang Romawi tidak memperkenankan lahirnya sebuah aristokrasi pribumi yang kuat. ${ }^{21}$ Dalam konteks inilah Yudas mengambil keputusan.

19 Ibid.

20 Max Isaac Dimont, Yahudi, Tuhan dan Sejarah, Sejarah Panjang Bangsa Yahudi dari Abad 20 sM hingga 20 M (Yogyakarta:IRCiSoD, 2018), 182.

21 Theissen, Gerakan Yesus, 126. 
Ketika berada dalam situasi sebagaimana digambarkan di atas, Yudas memerankan sebuah peran yang mengharuskan dia untuk mengambil keputusan. Ia mengambil keputusan tanpa tedeng aling-aling. Tidak ada pertemuan berjilid-jilid untuk sebuh keputusan politis yang penting dan menegangkan. Yudas berada dalam situasi yang dalam bahasa drama disebut sebagai "acting yang mekanis."22 Ia berusaha untuk menyampaian pesan dari "sang sutradara" dengan penguasaan panggung yang luar biasa. Peran Yudas dalam drama penyaliban Yesus adalah sebuah keputusan yang oleh Vanhoozer disebut sebagai "kemunafikan dalam akting yang mekanis". ${ }^{23}$ Ia memutuskan untuk meninggalkan kemunafikannya lalu menunjukkan "misi personalnya". Ia melampaui kesadaran kebersesamaan lalu masuk ke dalam interest pribadinya. Kemampuan melampaui kesadaran tersebut, dimaknai sebagai, kesadaran akan diri sendiri. Jika kita mengikuti alur berpikir Jean Paul Sartre, maka pergulatan bathin yang dilewati oleh Yudas sebelum mengambil keputusan merupakan ekspresi untuk "menghargai" martabat kebebasan. ${ }^{24}$ Keputusannya untuk meninggalkan lingkaran kebersesamaan merupakan ekpresi kebebasan dan penegasan akan nilai personalitasnya.

Hal berikut yang menarik untuk didiskusikan adalah keputusan Yudas untuk menjadi "penunjuk jalan" bagi prajurit dan penjaga Bait Allah yang disuruh oleh imamimam kepala dan orang-orang Farisi. (Yoh. 18:2-3, dan ayat-ayat parallel dari Injil Sinoptik). Yudas dalam konteks ini tidak menyembunyikan diri atau hanya menunjukkan lokasi lalu menghilang. Tetapi, “...datanglah Yudas ke situ...” (Yoh.18:3). Ia memutuskan untuk berjumpa dengan Yesus lalu memberi tanda bagi "serombongan besar orang yang membawa pedang dan pentung" (Mat. 26:47). Yudas menyatakan,"Orang yang akan kucium, itulah Dia " (Mat.26: 48). K. Riedel menyatakan, Yudas hendak menuntaskan "amarahnya" lantaran Yesus tidak memberikan kesejahteraan melainkan kemelaratan. ${ }^{25}$ Dalam hal ini, Riedel secara emosional menyatakan, "Judas tidak malu menjerahkan Tuhannja dengan setjara jang demikian."26

Kehadiran Yudas bersama rombongan yang menangkap Yesus menghadirkan dua penafsiran. Pertama, ia hendak menunjukkan kepada teman-temannya bahwa ia memiliki koneksi dengan penguasa Romawi pada saat itu. Dan, yang kedua adalah ia hendak menegaskan bahwa kemiskinan akan terus menyengsarakan diri sendiri dan orang lain. Penafsiran pertama terkait dengan keakuan, kesombongan dan pembuktian diri bagi orang lain. Sementara penafsiran yang kedua terkait dengan protes atas pengurapan Yesus dengan menggunakan minyak narwastu yang mahal harganya.

Terkait dengan hal yang kedua, Yudas hendak menyatakan, bahwa ia memiliki dasar yang kuat ketika menyampaikan protes atas peristiwa pengurapan di Betania. Secara tersirat Yudas memberi catatan bahwa jika kemiskinan dibiarkan merajalela maka rakyat akan sengsara. Karena itu, minyak narwastu atau barang-barang mahal lainnya mesti dijual untuk kemudian dijadikan sebagai alat diakonia. Keputusan Yudas untuk menerima 30 keping perak adalah penegasan atas penafsiran yang kedua. Jadi, Yudas mengambil keputusan untuk "menyerahkan - menjual" Yesus dapat dimaknai sebagai tanda protes atas kemiskinan yang merajalela.

22 Vanhoozer, Drama Doktrin, Suatu Pendekatan, 501.

23 Ibid.

${ }^{24}$ Kondrad Kebung, Rasionalisasi dan Penemuan Ide-ide, Esai tentang Manusia, (Jakarta: Prestasi Pustaka, 2008), 91.

${ }^{25}$ K. Riedel, Indjil Matius (Djakarta:Badan Penerbit Kristen, 1952), 363, 365.

26 Ibid. 
Catatan selanjutnya terkait dengan keputusan Yudas adalah penyesalan dan pengembalian uang yang ia perolah. Dengan menggunakan pendekatan hermeneutik Paul Ricouer, John Simon menolong kita untuk memahami keputusan Yudas melalui jalan pertobatan. Simon menyatakan, "Proses hermeneutik...bermakna meditatif yang dimulai dari diri (ego) dan kembali melalui yang lain (the other)". ${ }^{27}$ Yudas menyadari dirinya sebagai seorang murid yang telah melewati berbagai dinamika sosio-religius. Ia menyaksikan Yesus berdoa, membuat mujizat, mengusir setan dan mengajar dengan penuh kuasa. Pengalaman-pengalaman tersebut terinternalisasi dalam dirinya yang kemudian menjadi "semacam amunisi" dalam pengambilan keputusan untuk menyesali tindakan yang telah ia lakukan.

Kondisi ini semacam "peralihan jalur" demi kepentingan yang lebih besar. Dalam konteks ini, Simon menegaskan, bahwa pemahaman akan diri tidak pernah langsung, melainkan melalui jalan panjang memutar melewati tanda-tanda, symbol dan teks, termasuk lewat kehadiran orang lain. ${ }^{28}$ Keputusan Yudas melewati jalan panjang dan kemudian menghadirkan tanda melalui orang lain. Pertanyaannya adalah, "Apakah keputusan Yudas untuk menyesal lalu mengembalikan uang yang ia peroleh dari imamimam kepala dan ahli-ahli taurat menghapus aib masa lalunya?"

Tidak mudah untuk mengembalikan posisi Yudas sebagaimana ketika pertama kali ia dipanggil. Kita beruntung, ada konsep "Teologi Ingatan" yang dikembangkan oleh Binsar J. Pakpahan. Pakpahan dalam Prakata bukunya mengatakan, "Beberapa 'hantu ingatan' masa lampau kembali ke ruang publik ketika suasana politik di Indonesia memanas..."29 Itu berarti cerita kelam masa lalu tidak dapat dilupakan begitu saja. Tetapi justru menjadi "hantu" yang dapat menyerang siapa pun, baik secara positif maupun secara negatif. Pakpahan menegaskan bahwa "Mengingat penting untuk memberi tempat bagi cerita korban dan memberi dia pengakuan atas apa yang terjadi pada dirinya." 30

Catatan kritis atas keputusan Yudas untuk menyesali tindakannya bahkan mengakhiri hidupnya secara tragis adalah semacam "hantu" yang dapat dijadikan sebagai alat untuk melegitimasi dendam kepada siapa pun tanpa meminta klarifikasi kepada keluarga atau pun membiarkan sejarah secara objektik untuk bersaksi tentang sang tokoh. Yudas, apa pun cerita tentang masa lalunya, adalah salah satu murid Yesus yang menghiasi catatan-catatan para penulis Injil, baik Sinoptik maupun Injil Yohanes. Karena itu, penting untuk melihat dari perspektif memori pemulihan, sebagaimana dikembangkan oleh Pakpahan. Pakpahan menyatakan, "Memori pemulihan adalah memori penebusan."31 Cerita tentang masa lalu Yudas yang dibangun atas stigma perlu diberi ruang pemulihan dari sudut pandang eklesiologi agar cerita-cerita serupa tidak terulang bagi orang lain. Gereja, dalam konteks pemulihan, selalu bertindak sebagai saksi dan pembawa memori atas tindakan penyelamatan Allah melalui cerita Kristus. ${ }^{32}$

\section{Mewartakan Injil - Membagi Roti: Karya Holistik Gereja}

Salah sifat Gereja yang dikembangkan oleh Ebenhaezer I. Nuban Timo adalah sifat kudus. Nuban Timo menjelaskan bahwa sifat itu terkait dengan hakikat Gereja sebagai

\footnotetext{
${ }^{27}$ John C. Simon, Teologi Publik: Narasi, Idiologi, Kekuasaan dan Agama (Yogyakarta-Makassar: Kanisius - STT INTIM, 2017), 190.

${ }^{28}$ Ibid. 190.

${ }^{29}$ Binsar J. Pakpahan, Allah Mengingat, Teologi Ingatan sebagai Dasar Rekonsiliasi dalam Konflik Komunal (Jakarta: BPK Gunung Mulia dan Unit Publikasi dan Informasi STT Jakarta, 2017), xix.

30 Ibid.

31 Ibid., 216.

32 Ibid., 217.
} 
tempat berkumpulnya orang percaya. Penyebutan orang percaya tidak hanya menunjuk kepada orang-orang tertentu, tetapi kepada semua orang percaya. Karena itu Nuban Timo menggunakan sifat kudus dan bukan suci. Menurut Nuban Timo, suci berarti bebas dari dosa, tidak bernoda dan bercela. ${ }^{33}$ Gereja bukanlah tempat khusus bagi orang-orang suci. Tetapi, ia adalah bagi semua orang yang baik maupun tidak baik, yang Yahudi maupun non Yahudi, yang bersunat maupun tidak bersunat. Karena itu, bagi Nuban Timo Gereja bukanlah tempat yang sempurna dan bebas dari dosa bahkan steril dari segala bentuk aib. Sebab, anggota gereja adalah homo peccatores (manusia berdosa), tetapi dijadikan homo iustus. ${ }^{34} \mathrm{Gereja}$ adalah tempat, yang dalam teologi Paulus, kita menikmati anugerah Allah.

Sifat yang dikembangkan oleh Nuban Timo berjalan simetris dengan memori pemulihan yang dikembangkan oleh Pakpahan. Sifat kekudusan Gereja terletak pada kesediaannya untuk menerima berbagai pengalaman memilukan masa lalu kemudian dinarasikan secara baru dalam kerangka memori penebusan. Catatan-catatan tentang Yudas yang berujung pada penyesalan dan tindakan untuk mengembalikan "uang haram" merupakan sebuah proses dari memori pengkhianatan menjadi memori penebusan. Narasi-narasi pengkhiatan mesti terus diminimalisir agar maut tidak melantunan nyanyian penyandraan dalam requiem, sehingga tugas "membagi roti" tidak dipolitisasi oleh siapa pun. Tugas membagi roti tidak boleh dipisahkan dari tugas pewartaan Injil.

Yudas, dalam kritikannya atas tindakan Maria yang mengurapi Yesus dengan minyak narwastu yang mahal, secara prinsip sudah berada pada treck yang benar. Tetapi, motivasi untuk memperkaya diri kemudian hadir sebagai bagian dari interupsi atas tugasnya sebagai murid Yesus yang tidak hanya mengikuti Yesus ke mana saja Ia pergi, tetapi juga, “... harus memberi mereka makan.” (Mat. 14:16, dan pasal-pasal parallel dari Injil Sinoptik dan Injil Yohanes). Tugas ini yang harus dijadikan sebagai pembuktian atas "kepemimpian Yudas" setelah berarak menuju persekutuan umat kudus dalam sebuah pengakuan "memori penebusan". Gereja yang darinya kita belajar mengenal Yudas, perlu menerapkan konsep, "Memberitakan Injil - Membagi Roti" agar suasana persekutuan tidak lagi menjadi tempat diskusi tentang "hari ini makan apa?" Karena itu, Gereja tidak lagi hanya berbicara tentang "bagaimana menuju ke surga," tetapi bagaimana menata alam semesta sehingga mendatangkan kesejahteraan segenap ciptaan.

Tugas-tugas tersebut sangat erat kaitannya dengan karakter pemimpin di dalam gereja. Jika para pemimpin Gereja masih berkelut dengan upaya stigmatisasi terhadap sesama, maka tidak menutup kemungkinan, gereja secara keseluruhan terjebak dalam karakter Yudas dalam memori pengkhianatannya. Gereja dapat saja terjebak dalam keberpihakan yang semu. Solidaritas Gereja dapat saja dikembangkan atas motivasi politik personalitas para pemimpinnya. Akibatnya, Gereja tetap mengubur semangat warganya yang berusaha keluar dari kubangan pengkhianatan menuju memori penebusan sebagaimana telah dilakukan oleh Yudas.

Terdapat dua hal yang dapat dijadikan sebagai langkah konkrit dalam tugas gereja sebagai "pewarta Injil - pembagi roti." Pertama, gereja perlu mewujudkan pemberitaan Firman Tuhan yang berisi penciptaan manusia dan dunia baru dalam kehidupan sehari-

33 Ebenhaezer I. Nuban Timo, Meng-Hari-Ini-Kan Injil di Bumi Pancasila (Jakarta: BPK Gunung Mulia, 2017), 75.

34 Ibid. 
hari. ${ }^{35}$ Tugas pertama ini terkait dengan ekpresi transformatif dari memori pengkhianatan menjadi memori penebusan. Gereja tidak hanya berbicara tentang surga, tetapi berbicara tentang bagaimana mempersiapkan warganya agar kelak masuk surga dalam kondisi sehat jasmani dan rohani. Kedua, pemulihan dan pemberdayaan.

Widyatmadja menyebutkan bahwa ada hubungan yang erat antara diakonia dan misi. ${ }^{36}$ "Pemberitaan Injil-Membagi Roti" adalah perwujudan diakonia (pemberdayaan) dan misi (pemulihan). Gereja berada pada dua jalur tersebut. Ia mewartakan misi Allah sambil berdiakonia. Gereja memberitakan Kerajaan Allah sambil mempersiapkan warga Kerajaan Allah agar hidup dalam suasana damai sejahtera. Suasana yang ditata, dikelola, dievaluasi, diperbaharui terus-menerus oleh para pemimpin gereja. Karena itu, para pemimpin Gereja mesti membuka diri atas perubahan yang terjadi, sambil tetap kritis atas perubahan-perubahan yang mereduksi nilai-nilai kekristenan. Para pemimpin gereja pun tetap terbuka atas memori-memori pengkhianatan, dendam, dan cerita kelam lainnya dalam proses pemulihan lalu mendampingi para penyintas sehingga tetap terjalin suasana persekutuan yang memuliakan Tuhan.

\section{Kesimpulan}

Dalam studi tokoh, Yudas selalu ditempatkan sebagai tokoh antagonis. Para penulis Injil pun sepertinya satu suara untuk menyebut Yudas sebagai tokoh antagonis. Dalam cerita pengurapan di Betania, status antagonis kembali menguat. Atas status tersebut, Yudas pada akhirnya "benar-benar" menjadi aktor di balik penangkapan Yesus. Yudas pun tidak segan-segan menjadi penunjuk jalan bagi pasukan prajut Romawi dalam drama penangkapan di Getsemani. Walau demikian, ia pun akhirnya menyesal dan berinisiatif untuk menemui imam-imam kepala dan ahli-ahli Taurat guna mengembalikan uang yang telah ia peroleh. Yudas, sekali lagi harus menerima kenyataan sebagai tokoh antagonis sekaligus penolakan.

Cerita-cerita di seputaran Yudas menghadirkan beberapa catatan kritis. Catatancatatan tersebut yang kemudian menjadi inspirasi bagi gereja dalam rangka pembaharuan yang terus-menerus dikerjakan oleh gereja. Pembaharuan-pembaharuan tersebut mewujud secara konkrit dalam kesediaan untuk mendengarkan narasi-narasi pengkhiatan yang pernah dilakukan pada masa lalu. Melalui narasi-narasi tersebut, Gereja kemudian berarak bersama sambil memberi ruang pemulihan bagi para pencipta sejarah masa lalu. Dalam arak-arakan tersebut, Gereja kemudian melayani umat Tuhan dalam spirit, "Mewartakan Injil - Membagi Roti."

\section{Referensi}

Abineno, J. L. Ch. Yesus Sang Mesias dan Sang Anak, Jakarta: BPK Gunung Mulia, td. Banawiratma, J. B. 10 Agenda Pastoral Transformatif, Yogyakarta: Kanisius, 2001.

Dimont, Max Isaac, Yahudi, Tuhan dan Sejarah, Sejarah Panjang Bangsa Yahudi dari Abad 20 sM hingga 20 M, Yogyakarta:IRCiSoD, 2018.

Gherd, Theisen, Gerakan Yesus, Sebuah Pemahaman Sosiologis tentang Jemaat Kristen Perdana, Maumere:Ledalero, 2005.

Haba, Jhon, Pendekatan Kualitatif, Sebuah Pengantar, dalam Robert Setio, Julianus Mojau, Yusak Soleiman, H. Ongirwalu, (Penyunting), dalam Prosiding: Studi Institut dan Metodologi Riset Ilmu Teologi, (Tomohon:Fakultas Teologi UKIT, 2012).

\footnotetext{
35 Yosef P. Widyatmadja, Yesus dan Wong Cilik, Praksis Diakonia Transformatif dan Teologi Rakyat di Indonesia, (Jakarta : BPK Gunung Mulia, 2010), 9.

36 Ibid., 10
} 
Hughes, John, The Politics of Forgiveness: A Theological Exploration of King Lear, Modern Theology, Vol. 17. No. 3, Juli 2001, (Oxford:Blackwell Publishers Ltd, 2001).

Kamus Besar Bahasa Indonesia dalam https://kbbi.web.id, (diakses 26 Oktober 2018).

Kebung, Kondrad, Rasionalisasi dan Penemuan Ide-ide, Esai tentang Manusia, Jakarta: Prestasi Pustaka, 2008.

Kleden, Paul Budi. "Memasang Panggung ke Masa Depan-Menyisir Masa Lampau, Menyimak Filsafat Sejarah Walter Benjamin, dalam Frans Ceunfin dan Felix Baghi," Mengabdi Kebenaran, Maumere: Penerbit Ledalero, 2005.

Mochammad Yuniar, Hidup dalam Stigma=Hidup Terpenjara, dalam www.kompasiana.com. (diakses 26 Oktober 2018).

Nuban Timo, Ebenhaezer I. Meng-Hari-Ini-Kan Injil di Bumi Pancasila, Jakarta: BPK Gunung Mulia, 2017.

Pakpahan, Binsar J., Allah Mengingat, Teologi Ingatan sebagai Dasar Rekonsiliasi dalam Konflik Komunal, Jakarta:BPK Gunung Mulia dan Unit Publikasi dan Informasi STT Jakarta, 2017

Pieris, Aloysius. Berteologi dalam Konteks Asia, Yogyakarta : Kanisius, 1996.

Riedel, K. Indjil Matius, Djakarta: Badan Penerbit Kristen, 1952.

Simon, John C. Teologi Publik: Narasi, Idiologi, Kekuasaan dan Agama, (YogyakartaMakassar:Kanisius - STT INTIM, 2017.

Soesilo, Anodya Ariawan, Teologi Proses Mengenal Allah dan Problem Kejahatan, Suatu Tinjauan atas Kasus Al-Nakhba, dalam Gema Teologi, Jurnal Teologi Kontekstual dan Filsafat Keilahian, Vol. 2, No. 2, Oktober 2017 (Yogyakarta: Fakutas Teologi UKDW, 2017).

Taylor, Justin. Asal-Usul Agama Kristen, Yogyakarta: Kanisius, 2008.

Tillich, Paul. The Religious Situasion, New York: Meridian Books, 1958.

Vanhoozer, Kevin J. Drama Doktrin, Suatu Pendekatan Kanonik-Linguistik pada Theologi Kristen, Surabaya: Penerbit Momentum, 2011.

Widyatmadja, Yosef P. Yesus dan Wong Cilik, Praksis Diakonia Transformatif dan Teologi Rakyat di Indonesia, Jakarta : BPK Gunung Mulia, 2010. 